DOI: https://doi.org/10.32839/2304-5809/2021-11-99-68

уДК 347.948

Меньших T.M.

Харківський науково-дослідний експертно-криміналістичний центр Міністерства внутрішніх справ України

\title{
ОСОБЛИВОСТІ ТОВАРОЗНАВЧОЇ ЕКСПЕРТИЗИ ОДЯГУ, ЩО БУВ У ВИКОРИСТАННІ
}

Анотація. У даній статті досліджено експертну діяльність як профресійну, в сфрері обігу товарів (одягу). Проаналізовано виникнення передумов необхідності і можливості проведення товарознавчої експертизи на базі попереднього вивчення інформації про товар, обстеження об'єкту, його дослідження, оформлення експертного висновку. На кожному етапі експертного дослідження вирішуються конкретні завдання, досліджуються певні властивості об'єктів. З'ясовано, що розвиток товарознавчої експертизи пов'язаний 3 набуттям чинності таких законів України: «Про захист прав споживачів», «Про основні засади державного нагляду (контролю) у сорері господарської діяльності», «Про державний ринковий нагляд і контроль нехарчової продукції» та «Про загальну безпечність нехарчової продукції», так і з посиленням конкуренції на товарних ринках, а також з поширенням поняття «товар» на ресурси, виконані послуги, роботи, інтелектуальну власність та активізацією зовнішньоекономічної діяльності й особливо з реакцією споживачів на недоброякісність товарів. Визначено, що в обірунтуванні претензій споживачів, визначальну роль грає товарознавча експертиза, яку професійно може проводити лише експерт-товарознавець. Тільки ретельний аналіз товарів дозволяе правильно вирішувати питання при їх оцінювані. При оцінці конкурентоспроможності товарів потрібно враховувати вимоги різних категорій споживачів. При виробництві виробів використовують найрізноманітніші матеріали. Кожен з цих матеріалів має комплекс своїх властивостей, які в асортиментній групі змінюються в широкому діапазоні. Пошив виробів (одягу) і технологічні режими їх виготовлення залежать від властивостей матеріалів. Методики вивчення споживчих оцінок повинні бути адаптовані для їх використання вітчизняними підприемцями. Рекомендовано зобов'язання щодо продавця (виробника) задовольнити вимоги споживача, якщо він не доведе, що недоліки товару виникли внаслідок порушення споживачем правил користування, зберігання або транспортування товару, дій третьої особи, сторони або форс-мажорних обставин.

Ключові слова: товар, споживач, експертиза одягу, товарознавство.

Menshikh Tetyana

Kharkiv research expert-criminological center of the Ministry of Internal Affairs of Ukraine

\section{FEATURES OF COMMODITY EXAMINATION OF CLOTHES THAT WAS USED}

Summary. This article examines the expert activity as a professional in the field of circulation of goods (clothing). The emergence of prerequisites for the need and possibility of conducting commodity examination on the basis of preliminary study of information about the product, inspection of the object, its research, registration of an expert opinion. At each stage of expert research specific tasks are solved, certain properties of objects are investigated. It was found that the development of commodity expertise is associated with the entry into force of the following laws of Ukraine: "On consumer protection", "On the basic principles of state supervision (control) in the field of economic activity", "On state market supervision and control of non-food products" and "On the general safety of non-food products", and with increasing competition in commodity markets, as well as with the extension of the concept of "goods" to resources, services, works, intellectual property and intensification of foreign economic activity and especially consumer response to substandard goods. It is determined that in substantiation of consumer claims, the decisive role is played by commodity expertise, which can be professionally conducted only by an expert commodity expert. Only a careful analysis of goods allows you to properly address issues when evaluating them. When assessing the competitiveness of goods must take into account the requirements of different categories of consumers. In the manufacture of products using a variety of materials. Each of these materials has a set of its properties, which in the assortment group vary in a wide range. Tailoring of products (clothes) and technological modes of their production depend on properties of materials. Methods of studying consumer assessments should be adapted for use by domestic entrepreneurs. It is recommended to oblige the seller (manufacturer) to satisfy the consumer's requirements, unless he proves that the defects of the goods arose due to violation by the consumer of the rules of use, storage or transportation of goods, actions of a third party, party or force majeure.

Keywords: goods, consumer, examination of clothes, commodity science.

$\Pi^{2}$ остановка проблеми. В останні роки все більш поширеними стають експертизи, які проводяться за якістю товарів, які вже були в експлуатації. Такі експертизи найчастіше проводяться відповідно до Закону України «Про захист прав споживачів». При продажу товару споживачеві, умови договору, зазвичай, визначаються положеннями стандартів. Такі дані містяться: у технічному паспорті на товар чи правилах щодо його використання, де вказуються основні технічні характеристики виробу та стандарти, вимогам яких має відповідати якість товару; на маркуванні товару - етикетці (або ярлику), прикріпленій до виробу, де вказується стандарт або ТУ.

Аналіз публікацій. У різні періоди проблеми використання спеціальних товарознавчих знань викликали цікавість вітчизняних 
та зарубіжних учених. Однак, питання особливості товарознавчої експертизи одягу, що був у використанні, були досліджені недостатньо. Окремі питання досліджувались у роботах М. С. Алексеєва, Н. І. Альхамова, В. В. Архіпова, В. Д. Арсеньева, К. А. Букалова, Л. І. Георгієва, Г. В. Дашкова, О. О. Закатова, Є. Г. Коваленка, С. С. Толмачової, О. І. Лозового, Я. С. Сапошинського, Л. О. Сергеєва та деяких інших.

Мета статті полягає в дослідженні особливостей товарознавчої експертизи одягу, що був у використанні.

Виклад основного матеріалу дослідження. Купуючи товар, споживач приймає до відома вимоги до якості, і тому вони стають умовами договору купівлі-продажу, що визначають якість придбаного товару. Так, якщо на ярлику трикотажного джемпера вказано склад: вовни - 70\%, то саме такого складу і має бути пряжа, з якої він виготовлений. Якщо споживач при носінні виявить, що продавець порушив умови договору купівлі-продажу, то в цьому випадку виникає спірна ситуація, для вирішення якої потрібна експертиза. На практиці широко поширений продаж за зразками, які виставляють у вітринах, викладають на прилавок. У цьому випадку споживачеві має бути передано товар тієї ж якості, що і товар, виставлений як зразок [1, с. 49].

Під «звичайною якістю» розуміеться усереднена оцінка товару, яка залежить від сформованих у суспільстві поглядів, що відбивають певний рівень його розвитку. У будь-якому суспільстві є люди з дуже високими, з нижчими та невисокими вимогами (запитами) до товарів. «Звичайна якість» або «звичайні вимоги» - щось усереднене між різними вимогами і означає "не нижче середньої якості». Тому що вище рівень розвитку суспільства, то вищі вимоги пред'являються до нормальної якості товарів.

Це досить складні експертизи внаслідок особливостей щодо об'єктів дослідження, які вже були у вжитку, а також через недостатньо розроблену методичну базу проведення таких експертиз. Особливість їх полягає в тому, що в пред'явленому на експертизу товарі встановлюють наявність не тільки явних і прихованих дефектів виробничого характеру, а й дефектів, що виникли внаслідок механічних та інших пошкоджень, що з'явилися при хімічному чищенні, застосуванні різних засобів догляду за виробом, прасування і т.п.

Отже, ідентифрікаційна частина дослідження повинна містити докладний опис та поділ дефектів з урахуванням їхнього походження. Однією 3 перешкод у практиці проведення товарознавчих експертиз нині $\epsilon$ розроблення і загальне визнання методик. Особливо важливим у методичному забезпеченні є градація дефектів однорідних груп товарів за рівнем їхнього впливу, зниження якості та виділення істотних дефектів.

Існують методики визначення зниження ціни нових товарів, які мають дефекти. Але в практиці товарознавчих експертиз ці методики використовуються рідко, тому що у разі суперечки між продавцем та споживачем останні найчастіше вимагають розірвання договору купівлі-продажу, а не зниження ціни товару. У Законі «Про захист прав споживачів» запроваджено поняття «істотний недолік товару» - непереборний недолік чи недолік, який може бути усунений без невідповідних витрат часу, або виявляеться неодноразово, чи проявляеться знову після його усунення, чи інші подібні недоліки [2].

Споживач має право пред'явити вимоги виробника після закінчення гарантійного строку або його відсутності тільки у разі виявлення суттевих недоліків товару. Тому при призначенні експертиз або заявок на їх проведення майже завжди ставиться питання про оцінку дефектів як суттевих (критичних, значних, незначних).

Однак часто оцінка значущості дефекту одним експертом без використання методик може бути не визнана в судовому порядку через їі суб'єктивність. Тому одним із завдань у товарознавчій експертизі $є$ розробка методики та градації недоліків товарів експертним методом: наприклад, таким методом визначено критичні вади взуття, що було в експлуатації [3, с. 13].

Одним із відповідальних моментів у проведенні експертизи товарів, що були в експлуатації (шкарпетки), є встановлення ступеня зниження якості виробу. Для цього експерт встановлює наявність не тільки прихованих десректів (недоліків) виробничого характеру, а й дефектів, що виникли внаслідок механічних та інших ушкоджень (впливів) або неналежного догляду за товаром, що залежать від його власника.

Ця обставина ускладнюе експертизу якості товарів та іноді призводить до неправильного висновку. До помилок таких експертиз відносять те, що деякі експерти у своїх висновках не дають диференціальних даних про зниження якості товару у зв'язку із прихованими дефектами (недоліками) виробничого характеру та у зв'язку 3 дефектами, які утворилися внаслідок звичайної експлуатащії або стали результатом випадкових пошкоджень (псування), недбалої експлуатації або неправильного користування тощо. У експертному висновку слід вказати назву дефектів, їх характер, розміри, місце розташування та причини їх походження [1, с. 13].

Отже, при проведенні експертизі необхідно, по-перше, виявити показники, якими зазначено зниження якості, i, по-друге, встановити зниження значень показників у відсотках. При цьому оцінку зниження якості, як показано вище, проводять окремо за дефектами виробничого характеру та дефектами, які виникли в процесі експлуатації (шкарпетки) і не є виробничими дефектами. Крім того, встановлюючи ступінь зносу товару за час експлуатації, експерт вказує, чи знос є незначним або значним. Для обгрунтування цього необхідно навести докази.

Отже, дедекти, які можна виявити при експертизі товарів, що були в експлуатації, експерти поділяють на три групи:

- видимі виробничі дефекти, що були на момент продажу;

- приховані виробничі дефекти, що проявилися під час експлуатації;

- експлуатаційні дефекти.

Перша група дефектів зазвичай описана в стандартах (наприклад, по одягу та взуттю тощо), і про них продавець повинен попередити покупця i, можливо, знизити ціну на товар. Суперечки виникають найчастіше за класифікаці- 
єю та встановлення причин виникнення двох інших груп дедектів. Наприклад, відрив каблука взуття може бути прихованим виробничим (неправильне кріплення), так і експлуатаційним дедектом [2, с. 17].

Тільки в результаті експертного дослідження можна отримати відповідь на це питання. При цьому експерт не може направити на випробування визначення міцності кріплення підбора стандартним методом на другій півпаpi внаслідок низки причин: норми міцності визначені для нового взуття, при носінні міцність знижуеться; випробування на одній півпарі не $\epsilon$ представницькими (вибірка - 3 пари); каблук може бути погано прикріплений лише на одній півпарі. У цьому випадку експерту складно обгрунтувати висновок, оскільки об'єкт не може бути підданий лабораторному дослідженню вимірювальними методами. Тому експерт має особливо старанно провести власні дослідження.

Його посилання на невідомі йому умови експлуатації чи зберігання товару є безпідставним. Однак можна навести інший приклад, коли експерт мав провести не лише власні дослідження, а й випробування у лабораторії. Так, при експертизі демісезонного пальта, яке було в експлуатації згідно товарного чеку близько двох місяців, експерт встановив потертості низу, кишень, низу рукавів і бортів в результаті експлуатації, зазначивши, що тканина дефектів не має. При цьому було вказано втрату якості $35 \%$. Це значно перевищує середньорічну норму зношування (10\%) [3, с. 17].

I лише за повторної експертизи було встановлено причину сильного зносу - нестійкість тканини до стирання, визначена стандартним методом. Отже, підвищене стирання тканини було прихованим виробничим дефектом, що виявився під час експлуатації. Слід зазначити, що випробування одягу, що було в експлуатації, на стійкість до стирання, стійкість забарвлення до тертя та інших впливів повинні проводитися на закритих ділянках, які не піддавалися носінню будь-якого впливу.

Крім того, слід враховувати, що під час проведення таких експертиз не завжди можна керуватися нормами, встановленими у стандартах, технічних умовах, договорах та інших нормативних документах. Як правило, показники формуються для нових товарів, а не для вживаних. Наприклад, не можна перевіряти мікробіологічну забрудненість крему, яким користувалися, або усадку тканини виробу, що пройшла прання (наприклад, портьер). Ряд нормованих показників, застосовуваних нових виробів, може бути використаний для експертизи одягових товарів, які були у експлуатації.

При експлуатації виробів знижуються властивості міцності матеріалів, і норми міцності вже не можуть бути використані при оцінці відповідності. Некоректними будуть випробування на стійкість фарбування до сухого та мокрого тертя після прання одягу тощо. Цю особливість під час проведення ТЕ експерти враховують не завжди. Так, найчастіше при експертизі взуття, що було в носінні, експерти вказують, що взуття не відповідае стандарту на визначення сортності взуття, яке поширюється на нове взуття.
Крім самого товару експерту можуть знадобитися документи, пов'язані 3 його покупкою та подальшою експлуатацією: договори, чеки, гарантійні талони, квитанції, інструкції з експлуатації тощо. При необхідності експертизу можуть бути представлені рекламні матеріали на товар. Це особливо важливо, якщо вирішуеться питання відповідності споживчих властивостей купленого товару тієї інформації, яка була доведена до споживача продавцем і визначила його вибір при покупці. Якщо вирішуються питання, пов'язані із встановленням умов транспортування, експлуатації та зберігання товару, то експерту можуть знадобитися упаковка, тара чи їхні фотоградрії. Іноді потрібна інформація про умови зберігання споживачем того чи іншого товару, наприклад, хутра [6, с. 13].

У таких товарах, як одягові та взуттеві, часто трапляються дефекти, причини яких полягають у невідповідному догляді за виробом або дефектах, що виникли внаслідок невідповідних правил догляду за виробами, які доведені до споживача. Однак часто вони вказують їх неправильно або застосовують символи, які не відповідають сировинному складу виробу.

Особливо це стосуеться виробів, виконаних 3 тканини, що складаеться 3 двох або більше компонентів. Наприклад, бавовняні або лляні тканини, декоративне оздоблення яких виконано $з$ поліамідних волокон, менш стійкі до дії високої температури. Для таких виробів необхідно вказувати символ 3 догляду за виробом (прасування) 3 урахуванням не тільки сировинного складу основної тканини, а й складу тканини обробки.

Якщо це не враховувати, ділянки 3 поліамідними волокнами оплавляються, порушуючи структуру тканини, що призводить до утворення дедекту. Хоча такий дефрект утворений у процесі експлуатації одягу під час догляду, але фрактично його експлуатаційним назвати не можна, оскільки причиною виникнення є невідповідна інформація щодо способу догляду за товарами.

Велика частка експертиз із одягових товарів пов'язана 3 такими дефектами, як поява плям невідомого походження. Найчастіше причиною появи плям $є$ прання неправильно підібраним синтетичним пральним засобом.

Відомо, що до більшості засобів входять хімічні відбілювачі або ензими. Тому застосування СМ3 вимагає великої обережності, оскільки в місцях потрапляння на вироби нерозчинених частинок миючого засобу змінюеться колір (тканина знебарвлюеться). Після сушіння споживач відзначає білі плями на одязі, припускаючи, що даний дефект має виробничий характер, який проявився після прання. Для встановлення характеру походження таких плям потрібно застосування експертного методу. Ще однією причиною виникнення плям може бути тривале замочування виробів перед пранням.

В даний час відповідно до тенденцій моди випускаються вироби з тканин у комбінації двох кольорів, що різко відрізняються не тільки за складом, але і за кольором. Виявлення причини походження плям такого роду ускладнюеться тим, що при дослідженні стандартним методом, тобто відповідно до вимог ГОСТ. Це відповідає 
нормам стандарту для звичайної міцності фрарбування. Поява плям відбувається лише в процесі тривалого впливу на виріб вологи та дотику при цьому тканин двох кольорів.

Відсутність у нормативних документах визначальних символів догляду за виробом, символу «уникати замочування» створюе певні труднощі 3 догляду і призводить до утворення плям такого роду. У деяких випадках укладачі текстів зазначають, що замочування не рекомендується. У практиці експертиз був випадок, коли такий текст залишився не перекладеним російською мовою, i, отже, інформацію було доведено до споживача.

Це призвело до появи плям після прання. Таким чином, неправильні відомості про волокнистий склад одягових товарів та неправильні вказівки щодо догляду за товаром у маркуванні (символи з догляду за виробом) можуть призвести до прояву дефектів на одязі при догляді за ним. Іноді на експертизу ставлять питання про те, чи товар був в експлуатації (споживання), i якщо був, то який час. Такі питання можуть виникнути при заміні нових товарів, які не мають недоліків, товар аналогічної марки (моделі, артикула).

Це досить складне питання, на яке може відповісти тільки досвідчений експерт, тому що необхідно дослідити ті ділянки виробу, які піддаються найбільшому механічному впливу при носінні або використанні товару. Забруднення на товарі не завжди свідчать про його використання, оскільки вони могли з'явитися під час зберігання та транспортування товару, зокрема безпосередньо після покупки.

У цьому випадку експерт досліджуе наявність можливих слідів експлуатації (шкарпетки) і робить висновок щодо поставлених питань. Оскільки інтенсивність експлуатації (шкарпетки) продуктів різними споживачами істотно відрізняеться, то непрямим доказом тривалості експлуатації може бути товарний чек. Якщо зовнішній вигляд товару свідчить про інтенсивну експлуатащію, то експерт повинен відобразити це у висновку. Іноді приховані дефекти виробничого характеру, виявлені покупцем у процесі експлуатації (шкарпетки), експерти відносять до дефектів, що виникають внаслідок порушень правил експлуатації.

Передумовою для проведення товарознавчої експертизи одягу $є$ замовлення, в якому поставлене одне або декілька питань, на які експертові необхідно відповісти. Саме такими питаннями при проведенні експертизи одягу, що використовувався, можуть бути: встановлення фракту зміни стану зовнішнього вигляду виробу, наданого на експертизу; визначення причини зміни зовнішнього вигляду та показників споживчих властивостей виробу, що можуть підтвердити ці зміни; встановлення фракту появи і причин дедектів з їх характеристиками за розмірами, локальним місцем їх розташування, наочністю та ступенем впливу на якість; оцінювання дефектів (недоліків) за ступенем - суттєві, несуттєві; допустимі, недопустимі; явні, приховані; усувні, неусувні; встановлення кількості i якості матеріалів, використаних при виробництві виробу: основного, додаткового (докладного, утеплювального, оздоблювального, ниток, фрурнітури); встановлення відповідності виробів вимогам нормативної документації (технічних регламентів, правил торгівлі, інструкцій з експлуатації та догляду); встановлення умов та сезонності використання, їх впливу на появу дефектів та збереження показників споживних властивостей; встановлення фракту та попередження споживача про особливі властивості виробу, умови його зберігання, експлуатації та догляду.

При попередньому дослідженні виробу, наданого на експертизу, важливо ретельно проаналізувати додані документи та встановити, яка ще мається індрормація, необхідна експерту. Найчастіше недостатньою $є$ індрормація про умови користування виробом, технології обробок в хімчистці, режими окремих процедур по догляду за одягом.

В процесуальному досвіді існують випадки, коли при проведенні експертизи, 3 будь-яких причин, в розпорядження експерта неможливо представити безпосередньо вироби, або зразки чи упаковку, а також не можуть бути досліджені процеси, які саме могли відбуватися з виробами. Тоді единим джерелом інформації для експерта $є$ документи, що містять інформацію щодо товарних характеристик досліджуваних виробів; їх фрактичний стан; дії які відбувалися 3 виробом; стан упаковки; умови транспортування, зберігання, приймання і експлуатації виробу [6].

Висновки. Отже, якщо на експертизу представлений товар, що був в експлуатації і ремонті, то при класифрікації дефректів до вищевказаних трьох груп додають дефекти ремонту товару. Це саме стосуеться товарів, що надійшли на експертизу після хімчистки. Такі експертизи є ще складнішими та їх рекомендуеться проводити як комплексні, із залученням знань експертів інших галузей, а за їх відсутності - спеціалістів (з ремонту, хімчистки тощо).

Таким чином, експертна діяльність, як професійна, в сорері обігу товарів стрімко розвивається. Цей розвиток пов'язаний як з набуттям чинності таких Законів України: «Про захист прав споживачів", "Про основні засади державного нагляду (контролю) у сорері господарської діяльності», «Про державний ринковий нагляд і контроль нехарчової продукції» та «Про загальну безпечність нехарчової продукції, так i 3 посиленням конкуренції на товарних ринках; поширенням поняття «товар» на ресурси, виконані послуги, роботи, інтелектуальну власність; активізацією зовнішньоекономічної діяльності й особливо 3 реакцією споживачів на недоброякісність товарів. Якраз в обгрунтуванні претензій споживачів, продавців, визначальну роль грає товарознавча експертиза, яку професійно може проводити експерт-товарознавець. Лише він завдяки спещіальним знанням, набутим навичкам і досвіду, може ретельно проаналізувати виникнення передумов необхідності і можливості проведення товарознавчої експертизи; на базі попереднього вивчення інформації про товар, обстеження об'екту, його дослідження (випробування) оформити експертний висновок. 


\section{Список літератури:}

1. Лозовий А. І., Донцова О. С., Бобрицький С. М., Стебіх О. I. Методика визначення вартості майна. Харків : ХНДІСЕ, 2018. $112 \mathrm{c}$.

2. Закон України «Про захист прав споживачів» від 12.05.1991 № 1023-XII (із змінами та доповненнями). URL: https://zakon.rada.gov.ua.

3. Кардаш Н. М. Деякі особливості визначення вартості товарів (майна) при проведенні товарознавчих досліджень. Криміналістичний вісник : наук.-практ. збірник / Держ. наук.-дослід. експерт.-криміналіст. центр МВС України, Київ. нац. ун-т внутр. справ. Київ : Ін Юре, 2016. № 2(6). С. 146-149.

4. Артюх Т. М., Григоренко I. В. Теоретичні основи товарознавства : навчальний посібник / Міністерство освіти і науки України, Національний університет харчових технологій. Київ : НУХТ, 2019. 263 с.

5. Поліщук Л. В., Кириченко О. В. Особливості товарознавчої експертизи одягу, що був у використанні : Матеріали I міжнародної науково-практичної інтернет-конференції. Полтава, 2014. С. 37-39.

\section{References:}

1. Lozovij A. I., Doncova O. S., Bobric'kij S. M., Stebih O. I. (2018) Metodika viznachennya vartosti majna [Methodology for determining the value of property]. Kharkiv: HNDISE.

2. Law of Ukraine "On Consumer Protection" [Ukrainian law on consumer protection] dated 12.05.1991 № 1023-XII (with changes and additions). Available at: https://zakon.rada.gov.ua

3. Kardash N. M. (2016) Deyaki osoblivosti viznachennya vartosti tovariv (majna) pri provedenni tovaroznavchih doslidzhen' [Some features of determining the value of goods (property) in the conduct of commodity research]. Kriminalistichnij visnik: nauk.-prakt. zbirnik / Derzh. nauk.-doslid. ekspert.-kriminalist. centr MVS Ukraïni, Kyiv. nac. un-t vnutr. sprav. Kyiv: In Yur, no. 2(6), pp. 146-149.

4. Artyuh T. M., Grigorenko I. V. (2019) Teoretichni osnovi tovaroznavstva: navchal'nij posibnik [Theoretical foundations of commodity science: Tutorial]. Ministerstvo osviti i nauki Ukraini, Nacional'nij universitet harchovih tekhnologij. Kyiv: NUHT.

5. Polishchuk L. V., Kirichenko O. V. (2014) Osoblivosti tovaroznavchoï ekspertizi odyagu, shcho buv u vikoristanni [Features of commodity examination of used clothes]: Proceedings of the I International Scientific and Practical Internet Conference in Poltava. 